\title{
Exceptional durability enhancement of PA/PBI based polymer electrolyte membrane fuel cells for high temperature operation at $200^{\circ} \mathrm{C}$
}

Aili, David; Zhang, Jin; Jakobsen, Mark Tonny Dalsgaard; Zhu, Haijin; Yang, Tianyu; Liu, Jian; Forsyth, Maria; Pan, Chao; Jensen, Jens Oluf; Cleemann, Lars Nilausen

Total number of authors:

12

Published in:

Journal of Materials Chemistry A

Link to article, DOI:

$10.1039 /$ c6ta01562

Publication date:

2016

Document Version

Peer reviewed version

Link back to DTU Orbit

Citation (APA):

Aili, D., Zhang, J., Jakobsen, M. T. D., Zhu, H., Yang, T., Liu, J., Forsyth, M., Pan, C., Jensen, J. O., Cleemann, L. N., Jiang, S. P., \& Li, Q. (2016). Exceptional durability enhancement of PA/PBI based polymer electrolyte membrane fuel cells for high temperature operation at $200^{\circ} \mathrm{C}$. Journal of Materials Chemistry A, $4(11)$, 40194024. https://doi.org/10.1039/c6ta01562j

\section{General rights}

Copyright and moral rights for the publications made accessible in the public portal are retained by the authors and/or other copyright owners and it is a condition of accessing publications that users recognise and abide by the legal requirements associated with these rights.

- Users may download and print one copy of any publication from the public portal for the purpose of private study or research.

- You may not further distribute the material or use it for any profit-making activity or commercial gain

- You may freely distribute the URL identifying the publication in the public portal 


\section{Journal Name}

\section{COMMUNICATION}

\section{Exceptional durability enhancement of PA/PBI based polymer electrolyte membrane fuel cells for high temperature operation at $200{ }^{\circ} \mathrm{C}$}

Received 00th January 20xx, Accepted 00th January 20xx DOI: $10.1039 / \mathrm{x} 0 \mathrm{xx} 00000 \mathrm{x}$

www.rsc.org/
David Aili, ${ }^{a}$ Jin Zhang, ${ }^{\mathrm{b}}$ Mark Tonny Dalsgaard Jakobsen, ${ }^{\mathrm{a}}$ Haijin Zhu, ${ }^{\mathrm{c}}$ Tianyu Yang, ${ }^{\mathrm{d}}$ Jian Liu, ${ }^{\mathrm{b}}$ Maria Forsyth, ${ }^{\mathrm{c}}$ Chao Pan, ${ }^{\mathrm{a}}$ Jens Oluf Jensen, ${ }^{\mathrm{a}}$ Lars Nilausen Cleemann, ${ }^{\mathrm{a}}$ San Ping Jiang ${ }^{\mathrm{b}, *}$ and Qingfeng $\mathrm{Li}^{\mathrm{a}, *}$
The incorporation of phosphotungstic acid functionalized mesoporous silica in phosphoric acid doped polybenzimidazole (PA/PBI) substantially enhances the durability of PA/PBI based polymer electrolyte membrane fuel cells for high temperature operation of $200{ }^{\circ} \mathrm{C}$.

High temperature operation of polymer electrolyte membrane (PEM) fuel cells allows for better fuel impurity tolerance and catalyst kinetics as well as simplified cooling systems. ${ }^{1}$ Membranes of phosphoric acid (PA) doped polybenzimidazole (PBI, Scheme $\mathrm{S} 1, \mathrm{ESI} \dagger)^{2-4}$ or pyridine containing aromatic polyethers ${ }^{5}$ are among the most promising electrolyte systems in this connection, showing high proton conductivity at low water activity as well as good thermal and oxidative stability. Great progress has been achieved in this field and lifetimes of up to $18,000 \mathrm{~h}$ have been reported by several groups at constant current load as well as under dynamic operation at intermediate temperatures up to about $160{ }^{\circ} \mathrm{C}^{6-11}$ While electrode related degradation seem to be most significant during idling ${ }^{12}$ or shutdown/start-up, ${ }^{13}$ membrane degradation or acid redistribution predominate during operation at high current loads. ${ }^{14-16}$ In the higher end of the operating temperature regime $\left(180-200{ }^{\circ} \mathrm{C}\right)$ the PA loss rate increases considerably, eventually leading to acid depletion and proton conductivity decay. ${ }^{6}{ }^{17}$ High water activities, i.e. operation at high current loads, further promote this mechanism, ${ }^{6}, 18$ due to suppressed pyrophosphate formation. ${ }^{19}$ For example, the PA leaching rate at the cathode at $190{ }^{\circ} \mathrm{C}$ has been found to be about an order of magnitude higher than at $160{ }^{\circ} \mathrm{C} .{ }^{6,20}$ As a result, the durability data reported in the literature at $190-200{ }^{\circ} \mathrm{C}$ do not extend to much more than a few hundred hours of operation. ${ }^{3,6,9}$ Increasing the operating temperature from 160 to $200{ }^{\circ} \mathrm{C}$ is, however, strongly

beneficial due to further improved catalyst kinetics and fuel impurity tolerance in combination with better possibilities for thermal integration with fuel processing units. ${ }^{21-24}$ It is therefore of great interest to improve the long term stability under such challenging operating conditions, where the utilization of composite membranes has proven a successful approach. ${ }^{25-27}$

The proton conductivity and cell performance of composite membrane can be improved by incorporating functionalized nano- or mesoporous silica materials such as phosphorylated hollow mesoporous silica submicrospheres, ${ }^{28}$ PBIfunctionalized silica nanoparticles,${ }^{29}$ ionic liquid-functionalized mesoporous silica, ${ }^{30}$ phosphotungstic acid functionalized mesoporous silica by gel-casting technique, ${ }^{31}$ and proton conducting groups functionalized mesoporous silica. ${ }^{32}$ We have previously reported that phosphotungstic acid $\left(\mathrm{H}_{3} \mathrm{PW}_{12} \mathrm{O}_{40} \cdot n \mathrm{H}_{2} \mathrm{O}\right.$, PWA) functionalized mesoporous silica (PWA-meso-SiO 2 ) shows high proton conductivity of $34 \mathrm{mS} \mathrm{cm}^{-}$ ${ }^{1}$ and encouraging fuel cell performance at $200{ }^{\circ} \mathrm{C} .{ }^{33}$ Herein, we demonstrated that the introduction of PWA-meso- $\mathrm{SiO}_{2}$ into the PA/PBI matrix significantly improves the fuel cell durability in the high end of the operating temperature regime. Stable operation was achieved under dry conditions at $200{ }^{\circ} \mathrm{C}$ for 2,700 $\mathrm{h}$ at a load of $200 \mathrm{~mA} \mathrm{~cm}{ }^{-2}$, which is a significant milestone in the high temperature PEM fuel cell development.

\footnotetext{
a. Department of Energy Conversion and Storage, Technical University of Denmark, Kemitorvet 207,DK-2800 Lyngby, Denmark.Email: qfli@dtu.dk

b. Fuels and Energy Technology Institute \& Department of Chemical Engineering, Curtin University, Perth, WA 6102, Australia. Email: s.jiang@curtin.edu.au

c. Institute for Frontier Materials, Deakin University, Geelong, VIC 3220, Australia.

d. Australian Institute for Bioengineering and Nanotechnology (AIBN), The

University of Queensland, Brisbane, QLD 4072, Australia

+ Footnotes relating to the title and/or authors should appear here.

Electronic Supplementary Information (ESI) available: [details of any supplementary information available should be included here]. See DOI: 10.1039/x0xx00000x
} 

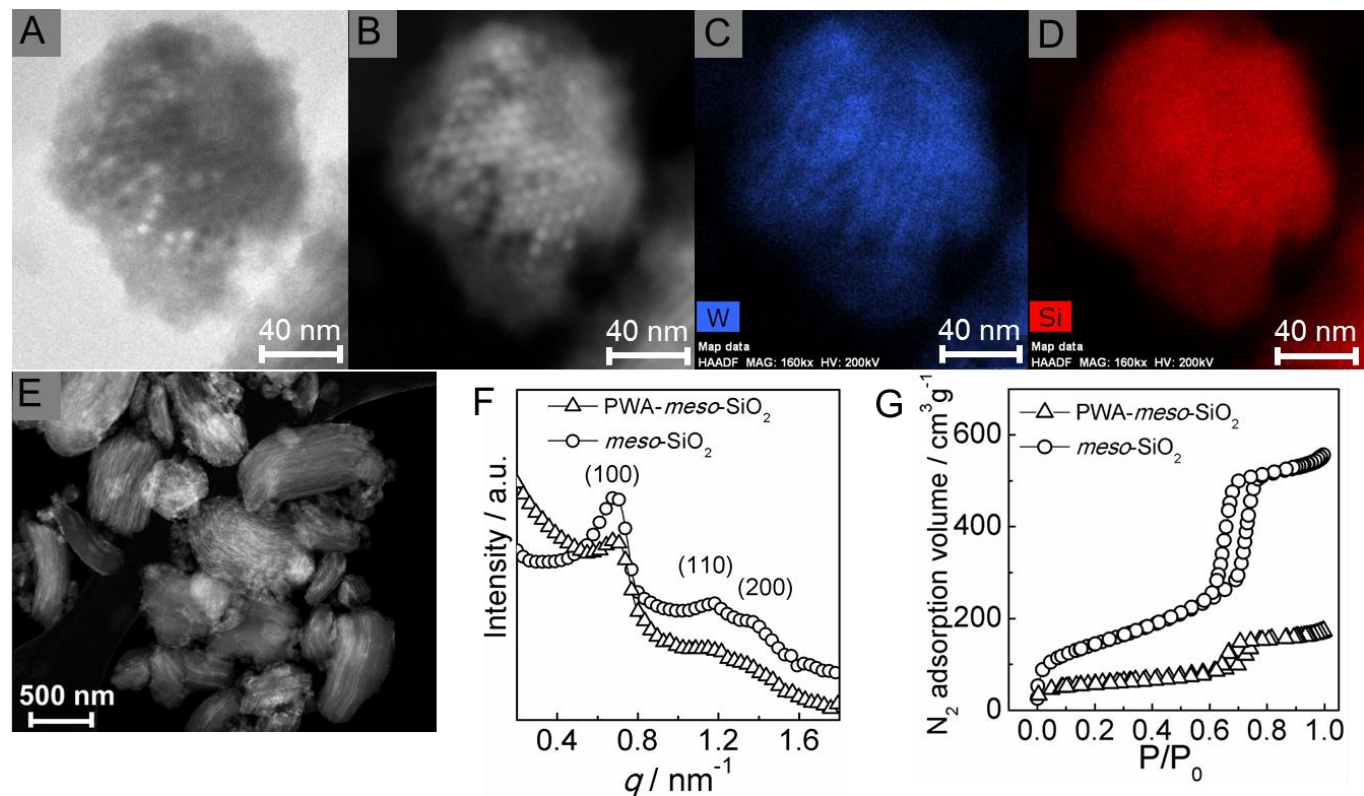

Fig.1 (A) Bright field TEM, (B) HAADF STEM image and corresponding (C) Si and (D) W element mapping for the PWA-meso-SiO ${ }_{2}$; (E) large scale HAADF STEM image for PWA-meso-SiO ${ }_{2}$; (F) SAXS patterns and (G) $\mathrm{N}_{2}$ adsorption isotherm of $m e s o-\mathrm{SiO}_{2}$ and $\mathrm{PWA}-m e s o-S i O_{2}$.

PWA-meso- $\mathrm{SiO}_{2}$ fillers were character by the bright field transmission electron microscopy (TEM) and small angle X-ray scattering (SAXS). TEM image in Fig.1A shows (100) plane of PWA-meso- $\mathrm{SiO}_{2}$ particle. The corresponding high angle annular dark field (HAADF) scanning transmission electron microscopy (STEM) image clearly shows hexagonal mesoporous channels of the PWA-meso-SiO $\mathrm{S}_{2}$ particle along [100] direction (Fig.1B). From the silicon (Fig. 1C) and tungsten (Fig. 1D) element mapping it can be seen that the mesoporous channels of meso$\mathrm{SiO}_{2}$ are filled with PWA, anchored to the mesoporous silica network through ionic interactions. ${ }^{34}$ The parallel white lines in the STEM image of PWA-meso-SiO 2 (Fig. 1E) compliments Fig.1B by further confirming that the pores of meso- $\mathrm{SiO}_{2}$ are filled with PWA along the [001] direction in large scales. The small angle X-ray scattering (SAXS) of meso-SiO 2 after PWA impregnation shows reduced intensity of the meso- $\mathrm{SiO}_{2}$ matrix (Fig.1F), indicating aggregation of PWA within the meso- $\mathrm{SiO}_{2}$ structure. ${ }^{35}$ Moreover, the scattering peak position after PWA impregnation remains unchanged, suggesting structural integrity. The $\mathrm{N}_{2}$ adsorption/desorption isotherms of meso- $\mathrm{SiO}_{2}$ and PWA-meso-SiO $\mathrm{S}_{2}$ show type IV adsorption curves with capillary condensation effect for the mesoporous structure and $\mathrm{H}$ 1 type hysteresis for cylindrical mesoporous structures (Fig. 1G). The Brunauer-Emmett-Teller surface area and Barrett-JoynerHalenda pore volume of meso- $\mathrm{SiO}_{2}$ are $507 \mathrm{~m}^{2} \mathrm{~g}^{-1}$ and $0.89 \mathrm{~cm}^{3}$ $\mathrm{g}^{-1}$, respectively, while they are sharply reduced to $196 \mathrm{~m}^{2} \mathrm{~g}^{-1}$ and $0.25 \mathrm{~cm}^{3} \mathrm{~g}^{-1}$ after PWA functionalization (Fig.1G), consistent with the STEM/TEM and SAXS results.

After surface modification of PWA-meso-SiO ${ }_{2}$ with dequalinium chloride hydrate (Scheme S1, ESI $\dagger$ ) to improve the dispersion in the PBI solution, homogenous composite membranes were obtained in the low PWA-meso-SiO 2 loading range up to $15 \mathrm{wt} \%$, as evidenced from the cross-sectional scanning electron microscopy imaging (Fig. $\mathrm{S} 1, \mathrm{ESI}+$ ). Loadings of PWA-meso-SiO 2 higher than $15 \mathrm{wt} \%$ resulted in anisotropic structures and pore formation, likely due to agglomeration of the inorganic component at high concentrations. Thus, in this study, the up-limit of PWA-meso-SiO 2 loading was $15 \mathrm{wt} \%$. Thermogravimetric analysis (TGA) was employed to confirm the PWA-meso-SiO $\mathrm{S}_{2}$ composition after casting and further demonstrated that the thermo-oxidative stability of the base materials was maintained (Fig. S2, ESI $\dagger$ ). The composite membranes were subsequently equilibrated in $85 \mathrm{wt} \% \mathrm{PA}$ at room temperature. The PA uptake was determined gravimetrically relative to the weight of the dry membrane, and was found to decrease gradually with increasing PWA-meso-SiO 2 loading (Fig. 2A), which is consistent with the negative effect of silica materials on the PA uptake of PA/PBI composite membrane. ${ }^{29}$ The pristine composite membrane has a dry thickness of $40 \mu \mathrm{m}$. The PA uptake of the pristine PBI membrane was $341 \mathrm{wt} \%$, corresponding to about $10.5 \mathrm{PA}$ per polymer repeat unit, as compared with $242 \mathrm{wt} \%$ for the composite with a PWA-meso- $\mathrm{SiO}_{2}$ loading of $15 \mathrm{wt} \%$. The elastic modulus and engineering tensile stress at break of the PA equilibrated composites was found to decrease with increasing PWA-meso-SiO ${ }_{2}$ (Fig. S3, ESI + ), likely due to discontinuities in the polymer phase. For example, the elastic modulus of the phosphoric acid doped pure PBI membrane was $52 \mathrm{MPa}$ as compared with $25 \mathrm{MPa}$ for the membrane with a PWA-meso- $\mathrm{SiO}_{2}$ loading of $40 \mathrm{wt} \%$, which is still sufficient for processing and membrane electrode assembly (MEA) fabrication.

The in-situ cross-sectional proton conductivity of the composite membranes at 160,180 and $200{ }^{\circ} \mathrm{C}$ was calculated from the fuel cell polarization data without humidification of the feed gases. The pristine PA/PBI membrane with PA uptake of $341 \mathrm{wt} \%$ showed proton conductivity in the range of $22-24 \mathrm{mS} \mathrm{cm}^{-1}$ at $160-200{ }^{\circ} \mathrm{C}$ (Fig. 2A), in consistence with the data in the literature. ${ }^{36}$ Although the PA uptake of the composite membranes significantly decreased with increasing PWA-meso-SiO 2 loading, the conductivity was still in a practically useful range. For example, the membrane with a PWAmeso- $\mathrm{SiO}_{2}$ loading of $40 \mathrm{wt} \%$, showed PA uptake of $215 \mathrm{wt} \%$ and insitu cross-sectional proton conductivity of 14 and $17 \mathrm{mS} \mathrm{cm}^{-1}$ at 160 ${ }^{\circ} \mathrm{C}$ and $200{ }^{\circ} \mathrm{C}$, respectively. Moreover, the decrease in the 


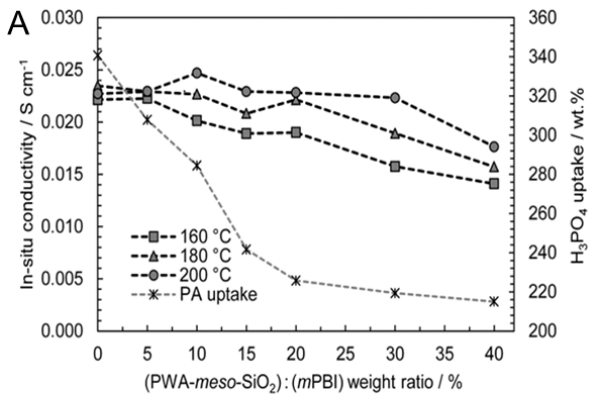

B
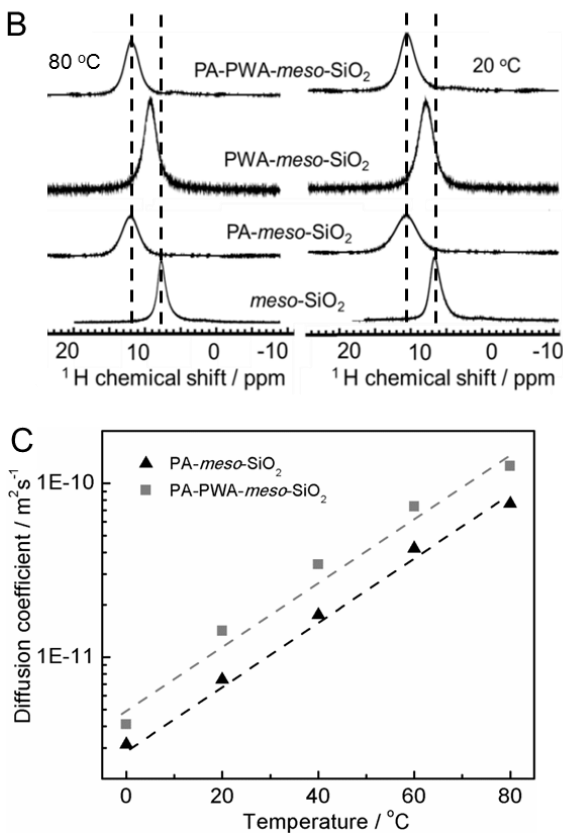

Fig.2 (A) In-situ proton conductivity at 160,180 and $200{ }^{\circ} \mathrm{C}$ for the PA doped membranes with PWA-meso-SiO ${ }_{2}$ loadings ranging from $0-40 \mathrm{wt} \%$; (B) ${ }^{1} \mathrm{H}$ chemical shift of meso- $\mathrm{SiO}_{2}$ with different proton conductors at different temperatures; (C) Proton diffusion coefficient in PA-meso-SiO ${ }_{2}$ and PA-PWAmeso- $\mathrm{SiO}_{2}$ at different temperatures.

PA uptake significantly reduces the volume swelling. For the membrane with a PWA-meso- $\mathrm{SiO}_{2}$ loading of $15 \mathrm{wt} \%$, the volume swelling ratio is $137 \%$, much lower than $203 \%$ of the pristine PA/PBI membrane (Table S1, ESI $\dagger$ ). The substantially reduced volume swelling is critical for the long-term stable operation of PA/PBI membrane based fuel cells.

In order to better understand the origin to the proton conductivity properties of the PWA-meso- $\mathrm{SiO}_{2}$ composite membranes, the proton mobility (Fig. 2B) and diffusion coefficients (Fig. 2C) of meso- $\mathrm{SiO}_{2}$ with different proton conductors were examined by pulse field gradient nuclear magnetic resonance (PFG-NMR) spectroscopy. The ${ }^{1} \mathrm{H}$ chemical shifts were found to move downfield with increasing acidity. Similarly, the ${ }^{1} \mathrm{H}$ resonance signals shifted downfield as the temperature was increased from 20 to $80{ }^{\circ} \mathrm{C}$ due to the weakening of the hydrogen bonding, which in turn indicates that increased temperature promotes the acid dissociation. In comparison with PWA-meso- $\mathrm{SiO}_{2}$, PA-meso- $\mathrm{SiO}_{2}$ shows higher ${ }^{1} \mathrm{H}$ chemical shift at both 20 and $80^{\circ} \mathrm{C}$, suggesting that PA is more dissociated than PWA. It is known that the proton line of water or organic solvent in microporous media is usually broad due to the restricted molecular motions, as well as the residual homonuclear dipolar couplings and susceptibility effect from the pore surfaces.$^{37}$ Therefore, the proton line width is sensitive to the molecular motions, and faster motions would lead to a narrower line width. The PA-PWA-meso-SiO 2 shows a slightly narrower proton line in comparison with PA-meso- $\mathrm{SiO}_{2}$, indicating that the proton in the former system is more mobile than the later one. In addition, the PA-PWA-meso- $\mathrm{SiO}_{2}$ shows systematically higher proton diffusion coefficients at all different temperatures measured than $\mathrm{PA}-m e s o-\mathrm{SiO}_{2}$ (Fig. 2C) suggesting a higher proton translational mobility with addition of PA. Both experimental and theoretical modelling demonstrate that PWA-meso$\mathrm{SiO}_{2}$ has the capability of high proton conductivity and high water retention due to the stability of PWA within the confined and ordered mesoporous silica structure. ${ }^{34,38}$

Fuel cell durability studies were conducted at $200^{\circ} \mathrm{C}$ and $200 \mathrm{~mA}$ $\mathrm{cm}^{-2}$, using the isotropic composite membranes with PWA-meso-SiO loadings of 0,5 , and $15 \mathrm{wt} \%$. The performance was evaluated from their steady state characteristics and from polarization curves, which were measured periodically during the test. From the representative polarization curves (Fig. 3A), it can be seen that the characteristics of the membrane-electrode assemblies (MEAs) are initially quite similar for the cells based on the composites with PWA-meso-SiO 2 loadings of 0 and $5 \mathrm{wt} \%$. The peak power density is $376 \mathrm{~mW} \mathrm{~cm}^{-2}$ and $386 \mathrm{~mW}$ $\mathrm{cm}^{-2}$ at $200{ }^{\circ} \mathrm{C}$ for $5 \mathrm{wt} \%$ and $15 \mathrm{wt} \%$ PWA-meso-silica added PA/PBI composite membranes, respectively, slightly lower than $408.6 \mathrm{~mW}$ $\mathrm{cm}^{-2}$ obtained on pristine PA/PBI composite membrane (Fig.3B). The slightly lower initial performance for the cell based on the composite with a PWA-meso- $\mathrm{SiO}_{2}$ is most likely due to interfacial contact limitations with the electrodes due to the stiffness of the composite membrane.

For the cell based on the pure PA/PBI membrane the cell voltage at $200 \mathrm{~mA} \mathrm{~cm}{ }^{-2}$ decreased from 0.71 to $0.53 \mathrm{~V}$ during the first $1450 \mathrm{~h}$, corresponding to a degradation rate of $129 \mu \mathrm{V} \mathrm{h}^{-1}$ (Fig.3C). It was followed by a rapid voltage drop of about $705 \mu \mathrm{V} \mathrm{h}^{-1}$. The impedance, as recorded on the pristine PA/PBI membrane cell operated in parallel, was measured every $8 \mathrm{hrs}$, showing a significant increase of the cell internal resistance of about $350-400 \%$ after $320 \mathrm{~h}$ and a much smaller (about $40-50 \%$ ) increase of the electrode polarization resistance (Fig.S4, ESI $\dagger$ ), likely a consequence of reduced proton conductivity due to the dehydration and out-leaching of the acid of pristine $\mathrm{PA} / \mathrm{PBI}$ membrane cells at this high operational temperature $\left(200{ }^{\circ} \mathrm{C}\right) .{ }^{17}$ By adding $5 \mathrm{wt} \%$ PWA-meso-SiO 2 to the membrane, the degradation was significantly reduced to $82 \mu \mathrm{V} \mathrm{h}^{-1}$ during the first $1660 \mathrm{~h}$. Thereafter the cell voltage decay rate increased dramatically to $840 \mu \mathrm{V} \mathrm{h}^{-1}$.

The performance degradation of PEM fuel cells via the dehydration and leaching of the acid ${ }^{17}$ can be substantially suppressed by increasing the PWA-meso- $\mathrm{SiO}_{2}$ concentration. By increasing the amount of PWA-meso-SiO 2 in the membrane to $15 \mathrm{wt} \%$, the durability was significantly improved as further supported by the stable in-situ conductivity (Fig.3D). Except for the initial reduction of performance, the cell voltage decay during $2700 \mathrm{~h}$ was found to be as low as $27 \mu \mathrm{V} \mathrm{h}^{-1}$, which is comparable and significantly better than the degradation rate of $25 \mu \mathrm{V} \mathrm{h}^{-1}$ at $160{ }^{\circ} \mathrm{C}, 3944 \mu \mathrm{V} \mathrm{h}^{-1}$ at $170{ }^{\circ} \mathrm{C}^{6}$ and $60 \mu \mathrm{V} \mathrm{h}^{-1}$ at $190{ }^{\circ} \mathrm{C}^{40}$ As shown in Fig.3E, the stability performance of the $15 \mathrm{wt} \%$ PWA-meso- $\mathrm{SiO}_{2}-\mathrm{PA} / \mathrm{PBI}$ membrane cell is exceptional as compared to those reported in the literature so far for PA/PBI membrane based cells at 190 and $200{ }^{\circ} \mathrm{C}$. Oono et at tested a commercial PA/PBI membrane cell with Pt catalysts loading of 0.8 
mg cm${ }^{-2}$ for both anode and cathode at $190^{\circ} \mathrm{C}$ and observed the sharp drop in performance stability after $1000 \mathrm{~h}$ operation. ${ }^{9}$ The rapid degradation in the cell performance was found to be caused by the significant increase of the internal resistance. In the case of $p$-PBI or commercial PA/PBI MEA (P-1000) based cells tested at $200^{\circ} \mathrm{C}$, the reported stability is very poor, no more than a few hundred hours. ${ }^{41,42}$
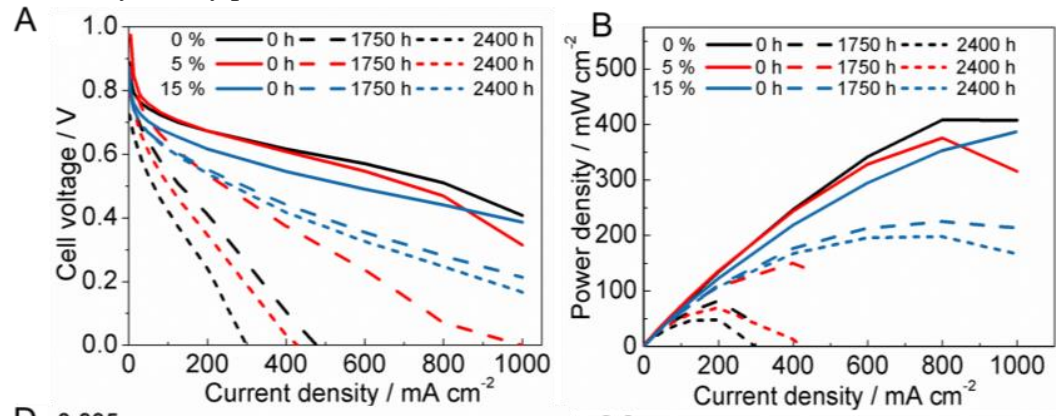

It should also be mentioned that the durability data for the cells in the present work were acquired at significantly higher gas-stoichiometry for both hydrogen and air, which is an additional stress-factor. Evidently, the stability of the PA/PBI composite membrane based fuel cell increases substantially with the addition of PWA-meso- silica fillers. This is also supported by the high stability of the open
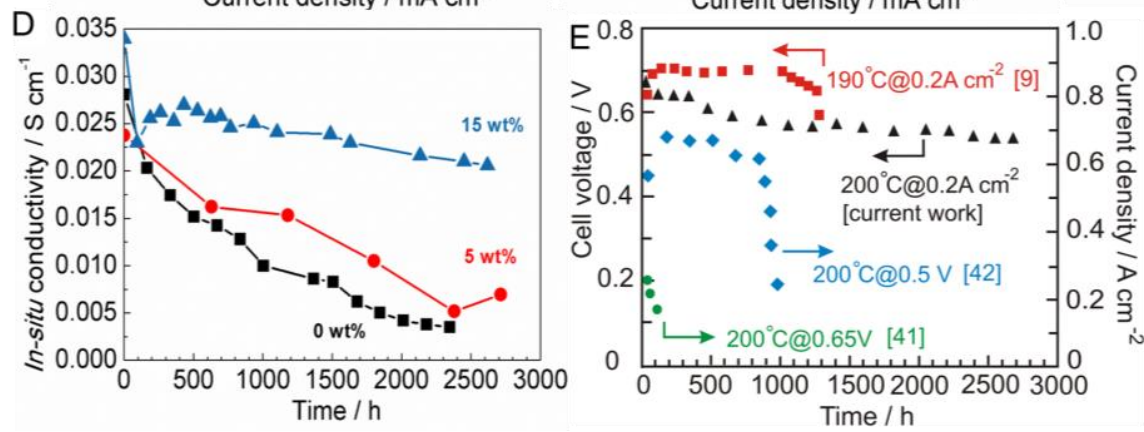

Fig.3 (A) Polarization curves and (B) power output curves for fuel cells based on the composites with $\mathrm{PWA}_{-m e s o-S i O}$ loadings of 0,5 and 15 wt $\%$; (C) Longterm stability tests of corresponding fuel cell operated at $200 \mathrm{~mA} \mathrm{~cm}^{-2}$ and $200{ }^{\circ} \mathrm{C}$; (D) Variation of the in-situ membrane conductivity with time; (E) Comparison of the $15 \mathrm{wt} \% \mathrm{PWA}-m e s o-\mathrm{SiO}_{2}$-PA/PBI membrane cell measured at $200{ }^{\circ} \mathrm{C}$ with those reported in the literature on PA/PBI membrane cells measured at $190{ }^{\circ} \mathrm{C}$ and $200{ }^{\circ} \mathrm{C}$. Numbers in (E) are references cited.
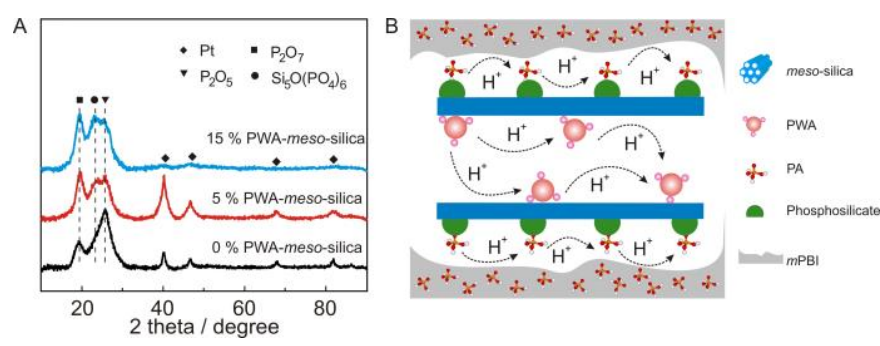

Fig.4 (A) XRD profiles of various PA/PBI composite membranes with 0,5 and $15 \mathrm{wt} \%$ PWA-meso-SiO 2 after durability test; (B) scheme of proton conduction paths through the attached and stabilized PA and PWA anchored inside the mesoporous channels of meso-silica at high temperatures.

circuit voltage of PA/PBI composite membrane cells with addition of 15wt\% PWA-meso-silica (Fig. S5, ESI $\dagger$ ).

Fig.4A shows the X-ray diffraction patterns (XRD) of various $\mathrm{PA} / \mathrm{PBI}$ membrane cells after the durability test at $200{ }^{\circ} \mathrm{C}$, as shown in Figure 3C. In the case of pristine PA/PBI membrane cells, there is a significant formation of $\mathrm{P}_{2} \mathrm{O}_{5}$ and $\mathrm{P}_{2} \mathrm{O}_{7}$, an indication of the thermal instability of phosphoric acid, $\mathrm{H}_{2} \mathrm{PO}_{4}$ at $200^{\circ} \mathrm{C}$. The decomposition of $\mathrm{PA}$ explains the high degradation of pristine $\mathrm{PA} / \mathrm{PBI}$ membrane cells as shown in Fig.3A. However, after the addition of PWA-meso-silica, a new peak centered at $23.5^{\circ}$ corresponding to the phosphosilicate phase, $\mathrm{Si}_{5} \mathrm{O}\left(\mathrm{PO}_{4}\right)_{6}$ was detected. And the intensity of the peak of $\mathrm{Si} 5 \mathrm{O}\left(\mathrm{PO}_{4}\right)_{6}$ increased with the improvement of PWA-meso-silica loading. The peak intensity associated with $\mathrm{P}_{2} \mathrm{O}_{5}$ was obviously decreased, indicating the reduction in the formation of $\mathrm{P}_{2} \mathrm{O}_{5}$. Mesoporous silica maintains the mesoporous structure in the present of phosphoric acid because of its high thermal stability ${ }^{43}$. Phosphosilicate shows high proton conductivity and stability at medium temperature ${ }^{44}$, similar as the effect of $\mathrm{Al}_{2} \mathrm{O}_{3}{ }^{45}$ and $\mathrm{TiO}_{2}{ }^{46}$ in phosphoric acid based high temperature PEMs on the reduction of the acid loss and the cell resistance. Thus, the presence of mesoporous silica in the PA/PBI composite membranes could stabilize phosphoric acid in the form of phosphosilicate, significantly increasing the thermal stability and decreasing PA loss during the fuel cell operation at $200{ }^{\circ} \mathrm{C}$. On the other hand, the facile and high proton diffusion ability of PWA confined in the mesopores of silica facilitates and maintains the high conductivity of the composite membranes, ${ }^{43}$ despite the reduction of PA uptake (Fig.2A). Proton conductivity can occur simultaneously through stabilized PA and PWA in the mesoporous silica, as shown schematically in Fig.4B. Consequently, the results demonstrate that inclusion of PWA-meso- $\mathrm{SiO}_{2}$ fillers inhibits the leaching and decomposition of the acid, resulting in the formation of a composite membrane with high proton conductivity and excellent stability at $200{ }^{\circ} \mathrm{C}$. Optimization of the catalyst and membrane interface should be able to significantly reduce the initial performance loss and further improve the cell performance and power output.

\section{Conclusions}


In this work, we developed a novel type of composite membranes based on phosphotungstic acid impregnated mesoporous silica functionalized phosphoric acid doped polybenzimidazole, PWAmeso-SiO 2 -PA/PBI. The composite membranes with $15 \mathrm{wt} \%$ of the PWA-meso-silica showed high proton conductivity and exceptional performance durability at significantly reduced phosphoric acid uptake and thus low volume swelling but with sufficient mechanical

\section{Acknowledgements}

David Aili and Jin Zhang contributed equally to this work. This work was financially supported by the Australia Research Council under the Discovery Project Scheme (project number: DP150102025 and DP150102044), ForskEl program (DuraPEM III) and Innovation Fund Denmark (4M Centre). The authors thank the assistance by Dr. Aaron Dodd and Dr. Martin Saunders for the STEM\&TEM characterization. The authors also acknowledge the facilities, and the scientific and technical assistance of the National Imaging Facility at the Center for Microscopy, Characterization\& Analysis, the University of Western Australia, a facility funded by the University, State, and Commonwealth Government.

\section{References}

1 Q. Li, R. H. He, J. O. Jensen, N. J. Bjerrum, Chemistry of Materials, 2003, 15, 4896-4915.

2 E. Quartarone, P. Mustarelli, Energy \& Environmental Science, 2012, 5, 6436-6444.

3 Q. Li, J. O. Jensen, R. F. Savinell, N. J. Bjerrum, Progress in Polymer Science, 2009, 34, 449-477.

4 T. Steenberg, H. A. Hjuler, C. Terkelsen, M. T. R. Sanchez, L. N. Cleemann, F. C. Krebs, Energy \& Environmental Science, 2012, 5, 6076 6080 .

5 J. K. Kallitsis, M. Geormezi, S. G. Neophytides, Polymer International, 2009, 58, 1226-1233.

6 S. Yu, L. Xiao, B. C. Benicewicz, Fuel Cells, 2008, 8, 165-174.

7 J. Mader, L. Xiao, T. J. Schmidt, B. C. Benicewicz, in Fuel Cells Ii, 2008, Vol. 216, pp. 63-124.

8 T. J. Schmidt, J. Baurmeister, Journal of Power Sources, 2008, 176, 428434.

9 Y. Oono, T. Fukuda, A. Sounai, M. Hori, Journal of Power Sources, 2010, 195, 1007-1014.

10 Y. Oono, A. Sounai, M. Hori, Journal of Power Sources, 2012, 210, 366373.

11 Y. Oono, A. Sounai, M. Hori, Journal of Power Sources, 2013, 241, 8793.

12 Z. Qi, S. Buelte, Journal of Power Sources, 2006, 161, 1126-1132.

13 T. Engl, L. Gubler, T. J. Schmidt, Journal of the Electrochemical Society, 2015, 162, F291-F297.

14 T. Arlt, W. Maier, C. Tötzke, C. Wannek, H. Markötter, F. Wieder, J. Banhart, W. Lehnert, I. Manke, Journal of Power Sources, 2014, 246, 290-298.

15 S. H. Eberhardt, M. Toulec, F. Marone, M. Stampanoni, F. N. Buchi, T. J. Schmidt, Journal of the Electrochemical Society, 2015, 162, F310 F316.

16 D. Aili, L. N. Cleemann, Q. Li, J. O. Jensen, E. Christensen, N. J. Bjerrum, Journal of Materials Chemistry, 2012, 22, 5444-5453.

17 C. Wannek, B. Kohnen, H. F. Oetien, H. Lippert, J. Mergel, Fuel Cells, 2008, 8, 87-95.

18 M. K. Daletou, M. Geormezi, E. Vogli, G. A. Voyiatzis, S. G. Neophytides, Journal of Materials Chemistry A, 2014, 2, 1117-1127.

19 W. Maier, T. Arlt, C. Wannek, I. Manke, H. Riesemeier, P. Kruger, J. Scholta, W. Lehnert, J. Banhart, D. Stolten, Electrochemistry Communications, 2010, 12, 1436-1438. robustness. As a result of the stabilization of phosphoric acid by the PWA-meso-SiO 2 filler, a fuel cell voltage decay rate of as low as 27 $\mu \mathrm{V} \mathrm{h}^{-1}$ was achieved during operation at $200{ }^{\circ} \mathrm{C}$ and $200 \mathrm{~mA} \mathrm{~cm}^{-2}$ for $2,700 \mathrm{~h}$. The fundamental reason for the exceptional durability of PWA-meso-SiO 2 -PA/PBI membrane is most likely due to the formation of phosphosilicate phase between the phosphoric acid and mesoporous silica.

20 S. H. Eberhardt, T. Lochner, F. N. Büchi, T. J. Schmidt, Journal of The Electrochemical Society, 2015, 162, F1367-F1372.

21 Q. Li, R. H. He, J. A. Gao, J. O. Jensen, N. J. Bjerrum, Journal of the Electrochemical Society, 2003, 150, A1599-A1605.

22 Q. Li, R. H. He, J. O. Jensen, N. J. Bjerrum, Fuel Cells, 2004, 4, 147 159.

23 C. Pan, R. He, Q. Li, J. O. Jensen, N. J. Bjerrum, H. A. Hjulmand, A. B. Jensen, Journal of Power Sources, 2005, 145, 392-398.

24 G. Qian, B. C. Benicewicz, in Polymer Electrolyte Fuel Cells 11, ed. by H. A. Gasteiger, A. Weber, S. R. Narayanan, D. Jones, P. Strasser, K. SwiderLyons, F. N. Buchi, P. Shirvanian, H. Nakagawa, H. Uchida, S. Mukerjee, T. J. Schmidt, V. Ramani, T. Fuller, M. Edmundson, C. Lamy, R. Mantz, Electrochemical Soc Inc, Pennington, 2011, Vol. 41, pp. 14411448 .

25 J. Lobato, P. Ca ̃̃ \pm izares, M. A. Rodrigo, D. Ãšbeda, F. J. Pinar, Journal of Power Sources, 2011, 196, 8265-8271.

26 F. J. Pinar, P. Canizares, M. A. Rodrigo, D. Ubeda, J. Lobato, RSC Advances, 2012, 2, 1547-1556.

27 F. J. Pinar, P. Cañizares, M. A. Rodrigo, D. Úbeda, J. Lobato, Journal of Power Sources, 2015, 274, 177-185.

28 Y. Zhao, H. Yang, H. Wu, Z. Jiang, Journal of Membrane Science, 2014, 469, 418-427.

29 Suryani, Y.-N. Chang, J.-Y. Lai, Y.-L. Liu, Journal of Membrane Science, 2012, 403-404, 1-7.

30 A. K. Mishra, N. H. Kim, J. H. Lee, Journal of Membrane Science, 2014, 449, 136-145.

31 L. Zhang, H. Q. He, R. K. S/O Abdul Rasheed, W. J. Zhou, Y. H. Xue, O. L. Ding, S. H. Chan, Journal of Power Sources, 2013, 221, 318-327.

32 Y. Zhao, H. Yang, H. Wu, Z. Jiang, Journal of Power Sources, 2014, 270, 292-303.

33 H. Tang, M. Pan, S. P. Jiang, Dalton Transactions, 2011, 40, 5220-5227.

34 Y. H. Zhou, J. Yang, H. B. Su, J. Zeng, S. P. Jiang, W. A. Goddard, Journal of the American Chemical Society, 2014, 136, 4954-4964.

35 S. F. Lu, D. L. Wang, S. P. Jiang, Y. Xiang, J. L. Lu, J. Zeng, Advanced Materials, 2010, 22, 971-976.

36 D. Aili, T. Allward, S. M. Alfaro, C. Hartmann-Thompson, T. Steenberg, H. A. Hjuler, Q. Li, J. O. Jensen, E. J. Stark, Electrochimica Acta, 2014, 140, 182-190.

37 H. Zhu, H. P. Huinink, S. J. F. Erich, V. Baukh, O. C. G. Adan, K. Kopinga, Journal of Magnetic Resonance, 2012, 214, 227-236.

38 J. Zeng, S. P. Jiang, Journal of Physical Chemistry C, 2011, 115, 1185411863.

39 A. D. Modestov, M. R. Tarasevich, V. Y. Filimonov, N. M. Zagudaeva, Electrochimica Acta, 2009, 54, 7121-7127.

40 W. Maier, T. Arlt, C. Wannek, I. Manke, H. Riesemeier, P. Krüger, J. Scholta, W. Lehnert, J. Banhart, D. Stolten, Electrochemistry Communications, 2010, 12, 1436-1438.

41 C. Zhang, W. Zhou, M. M. Ehteshami, Y. Wang, S. H. Chan, Energy Conversion and Management, 2015, 105, 433-441.

42 Q. F. Li, High Temperature Proton Exchange membranes For Fuel Cells. Editor, Technical University of Denmark, Lyngby, Denmark, 2005 .

43 J. Zeng, B. He, K. Lamb, R. De Marco, P. K. Shen, S. P. Jiang, Acs Applied Materials \& Interfaces, 2013, 5, 11240-11248.

44 A. Matsuda, T. Kanzaki, K. Tadanaga, M. Tatsumisago, T. Minami, Electrochimica Acta, 2001, 47, 939-944.

45 H.-S. Oh, Y. Cho, W. H. Lee, H. Kim, Journal of Materials Chemistry A, 2013, 1, 2578-2581.

46 F. Javier Pinar, P. Canizares, M. A. Rodrigo, D. Ubeda, J. Lobato, Journal of Power Sources, 2015, 274, 177-185. 